\author{
ОСОБЛИВОСТІ СОЦІАЛЬНОЇ АДАПТАЦІЇ ДІТЕЙ

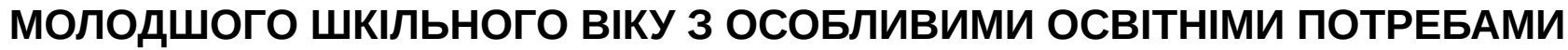 \\ В ІНКЛЮЗИВНОМУ ОСВІТНЬОМУ СЕРЕДОВИЩІ \\ PECULIARITIES OF SOCIAL ADAPTATION \\ OF PRIMARY SCHOOL CHILDREN WITH SPECIAL EDUCATIONAL NEEDS \\ IN INCLUSIVE EDUCATIONAL ENVIRONMENT
}

УДК 373.3:37.013.82

DOI https://doi.org/10.32843/2663-

$6085 / 2021 / 41 / 1.14$

\section{Соколова Г.Б.,}

докт. психол. наук,

доцент кафедри дефектології

та фрізичної реабілітації

Південноукраїнського національного

педагогічного університету

імені К.Д. Ушинського

Колбіна Л.А.,

канд. пед. наук,

доцент кафредри педагогічних

технологій початкової освіти

Південноукраїнського національного

педагогічного університету

імені К.Д. Ушинського
Статтю присвячено актуальній проблемі соціальної адаптації дітей молодшого шкільного віку з особливими освітніми потребами в інклюзивному освітньому середовищі. Mema дослідження полягає в теоретичному обгрунтуванні проблеми соціальної адаптації дітей молодшого шкільного віку з особливими освітніми потребами в інклюзивному освітньому середовищі, а також в апробації ефрективності експериментальної програми щодо соціально-педагогічної профрілактики дезадаптації в таких дітей. Доведено, що соціальна адаптація дітей молодшого шкільного віку з особливими освітніми потребами - це процес пристосування таких дітей до умов соціального середовища та інтеграції в різні типи соціальних спільнот для повноцінного життя; формування адекватної системи відносин із соціальними об'єктами, засвоєння та прийняття соціальних норм і цінностей нового соціального середовища; формування соціального досвіду, становлення й розвиток дитини як цілісної особистості, сприйняття суспільством дітей із такими потребами як партнерів у взаємодіі.

Охарактеризовані особливості діагностичної роботи, яка проводилася на основі виділених чотирьох компонентів соціальної адаптованості дітей молодшого шкільного віку з особливими освітніми потребами, а саме: анатомо-срізіологічного, мотиваційного, емоційного, комунікативного. Висвітлені результати діагностичного дослідження за зазначеними компонентами. Так, анатомо-фрізіологічний компонент передбачав виявлення дітей молодшого шкільного віку з особливими освітніми потребами на основі висновку інклюзивного ресурсного центру; мотиваційний компонент передбачав виявлення рівня шкільної мотивації й адаптації за допомогою анкети «Дослідження рівня шкільної мотивації й адаптації» $\mathrm{H}$. Лусканової; емоційний компонент визначав рівень тривожності в дітей молодшого шкільного віку за допомогою методики діагностики тривожності в дітей молодшого шкільного віку (Р. Теммл, М. Доркі, В. Амен); комунікативний компонент визначав рівень соціальної адаптованості дітей молодшого шкільного віку з особливими освітніми потребами за допомогою авторського опитувальника «Визначення рівня соціальної адаптованості дітей молодшого шкільного віку з особливими освітніми потребами».

Ключові слова: особливі потреби, дimu з особливими потребами, діти з особливими освітніми потребами, інклюзія, інклюзивне освітнє середовище.

The article is devoted to the topical problem of social adaptation of primary school children with special educational needs in an inclusive educational environment. The purpose of the study is to theoretically substantiate the problem of social adaptation of primary school children with special educational needs in an inclusive educational environment and to test the effectiveness of the experimental program for socio-pedagogical prevention of maladaptation in these children. An attempt has been made to prove that the social adaptation of children of primary school age with special educational needs is a process of adaptation of such children to the conditions of the social environment and integration into different types of social communities for a full life; formation of an adequate system of relations with social objects, assimilation and acceptance of social norms and values of the new social environment; formation of social experience, formation and development of holistic personality and provision of society's acceptance of children with such needs as partners in interaction.

The peculiarities of diagnostic work, which was carried out on the basis of the selected four components of social adaptability of children of primary school age with special educational needs are characterized, namely: anatomical and physiological, motivational, emotional, communicative. The paper presents the results of the diagnostic study on the anatomical and physiological component, which provided for the identification of children of primary school age with special educational needs on the basis of the conclusion of the inclusive resource center; the motivational component involved identifying the level of school motivation and adaptation with the help of the questionnaire "Study of the level of school motivation and adaptation" by N. Luskanova; the emotional component determined the level of anxiety in primary school children using the method of diagnosing anxiety in primary school children (R. Temml, M. Dorky, $W$. Amen); the communicative component determined the level of social adaptability of primary school children with special educational needs by means of employing an author's questionnaire "Determining the level of social adaptability of primary school children with special educational needs".

Key words: special needs, children with special needs, children with special educational needs, inclusion, inclusive educational environment. 
Постановка проблеми в загальному вигляді. В Україні дедалі краще розвивається інклюзивна модель освіти, яка найповніше реалізує право на освіту дітей з особливими освітніми потребами.

3і зростанням кількості дітей 3 особливими освітніми потребами відбувається актуалізація зазначеної проблеми щодо забезпечення прав таких дітей, отримання якісної освіти, а головне створення для них інклюзивного середовища в усіх освітніх закладах.

Навчання в інклюзивних закладах освіти дітей молодшого шкільного віку з особливими освітніми потребами, з одного боку, допомагає їм адаптуватися до життєвих обставин, інтегруватися в загальний соціум, відчути себе повноцінними членами суспільства, повірити у свої сили, позбутися почуття ізольованості й відчуженості, що зрештою сприяє руйнуванню соціальних бар'єрів і сегрегації. 3 іншого боку, такий освітній процес навчає дітей із типовим рівнем розвитку спілкуватися та працювати разом, фрормує в них почуття відповідальності за товаришів, які потребують допомоги, емпатії, співчуття, тобто сприяє вихованню толерантного ставлення до дітей, які так чи інакше відрізняються від них.

Аналіз останніх досліджень і публікацій. Важливі аспекти проблеми дослідження висвітлено в наукових працях вітчизняних і зарубіжних авторів. Так, Г. Андрєєва, О. Василенко, Л. Данилюк, А. Колупаєва, М. Мудрик, А. Петровський, М. Швед та інші науковці вивчали соціальну адаптацію дітей з особливими освітніми потребами. Сутнісні характеристики інклюзивної освіти та ефрективні підходи до впровадження інклюзивної моделі в освітню практику були предметом досліджень таких учених, як Д. Аллен, А. Арнесен, В. Бондар, А. Воткінз, Д. Гарнер, А. Дайсон, T. Євтухова, І. Звєрєва, Р. Зіглер, А. Капська, П. Міттлер, Д. Мітчелл, Д. Річлер, О. Савченко, В. Синьов, С. Хлєбік, А. Шевцов та інші. М. Андрє$є в а$, Л. Коваль, І. Малишевська, О. Рассказова та інші автори розглядали особливості впровадження інклюзивного освітнього середовища.

Мета дослідження полягає в теоретичному обґрунтуванні проблеми соціальної адаптації дітей молодшого шкільного віку з особливими освітніми потребами в інклюзивному освітньому середовищі, а також в апробації ефективності експериментальної програми щодо соціально-педагогічної профрілактики дезадаптації в таких дітей.

Виклад основного матеріалу дослідження. Однією 3 важливих проблем сучасної системи освіти є проблема розвитку адаптаційних можливостей особистості та профрілактика дезадаптації у критичні періоди психічного розвитку дитини. Особлива увага звертається на дітей 3 особливими освітніми потребами, а саме на молодших школярів.
3 огляду на те, що адаптація відіграє вагому роль у процесі соціалізації, необхідно охарактеризувати цей процес, оскільки питання соціалізації особистості стає актуальною проблемою сьогодення.

Ми згодні з Г. Андрєєвою у визначенні поняття «соціалізація» як двостороннього процесу: з одного боку, це засвоєння індивідом (у нашому випадку дітьми $з$ особливими освітніми потребами) соціального досвіду шляхом входження в соціальне середовище, систему соціальних зв'язків; 3 іншого боку, це процес активного відтворення індивідом систем соціальних зв'язків за рахунок його активної діяльності, активного включення в соціальне середовище [1, с. 176]. Саме така соціалізація, на наше переконання, повинна відбуватися в дітей молодшого шкільного віку з особливими освітніми потребами. Але, за дослідженнями М. Швед, у сучасних умовах українські діти з вадами розвитку, на жаль, практично не мають рівного доступу до освіти, оскільки вони зазвичай навчаються у спеціальних освітніх закладах або ж їхній освітній процес проходить удома. Зазначена авторка у своєму науковому доробку доводить, що за таких умов процес соціалізації відбувається однобічно, ізольованість дитини позначається на всіх сорерах її життєдіяльності та не дає їй можливості повноцінно реалізувати свої потреби, здібності, таланти. Також учена переконана, що наявний досвід роботи 3 дітьми 3 особливими освітніми потребами свідчить про те, що кожен із цих дітей може адаптуватися в суспільстві, приносити йому користь, вести повноцінне життя в колі рідних, ровесників, друзів, тобто успішно соціалізуватися $[9$, c. 131$]$.

Своєю чергою О. Безпалько в «Енциклопедії для фрахівців соціальної сфери» за редакцією І. Звєрєвої трактувала поняття «адаптація» як процес взаємодії живих організмів і навколишнього середовища, який приводить до їх пристосування до умов життєдіяльності [3, с. 7]. Як зазначає дослідниця, це поняття виникло ще в XIX ст. та спочатку використовувалося лише в біології. Пізніше (і дотепер) воно стало застосовуватися не лише щодо життєдіяльності організмів, а й щодо особистості та колективної поведінки.

На переконання О. Безпалько, соціальна адаптація - це процес пристосування індивіда до умов соціального середовища, фрормування адекватної системи відносин із соціальними об'єктами, інтеграція особистості в соціальні групи, діяльність щодо засвоєння стабільних соціальних умов, прийняття норм і цінностей нового соціального середовища. Психологічна й соціальна адаптація перебувають у взаємозалежності. Без психологічної адаптації, що спонукає людину до адаптивної діяльності, яка немовби «дає старт» соціальній адаптації, остання просто була би неможливою. 
На характері розвитку соціальної адаптації позначаються індивідуальні психічні ознаки особистості (мислення, увага, пам'ять, почуття), характеристики темпераменту (інтенсивність, темп реакції, ригідність, пластичність) та риси характеру особистості (цікавість, відповідальність, комунікабельність, працелюбність чи ледарство) [3, с. 7-8]. Проте не можна переоцінювати вплив психіки на соціальну адаптацію людини, оскільки причини, що зумовлюють соціальну адаптацію та визначають її суть, лежать у соціальній сорері.

Протилежне значення процесу адаптації - дезадаптація. Згідно з науковими розвідками В. Лютого, дезадаптація $€$ наслідком порушення процесу соціальної адаптації індивіда - процесу активного пристосування до умов соціального середовища, під час якого він, з одного боку, набуває якостей, необхідних для життя в певних умовах, фрормує відповідний вимогам середовища та власним особливостям стиль поведінки, а 3 іншого змінює умови власного середовища відповідно до своїх потреб і можливостей. У випадку дезадаптації поведінка індивіда перестає бути адекватною вимогам оточення, він втрачає можливість задовольнити базові чи найважливіші для нього потреби, і збереження цієї ситуації загрожує соціальному або фрізичному існуванню індивіда, а покращити її самостійно він не може [3, с. 331].

Дезадаптація, зокрема соціальна, дітей молодшого шкільного віку з особливими освітніми потребами не $є$ раптовим і непередбачуваним явищем, зазвичай вона фрормується тривалий час, а ії початок простежується ще з дошкільного віку. На ії виникнення та фрормування впливають як індивідуальні особливості дитини, так і найближче соціальне оточення. Тому вагоме місце відводиться саме профрілактиці дезадаптації в дитячому віці, адже запобігти її появі набагато легше, ніж пізніше усувати її негативні наслідки.

Щоб захистити та підтримати дітей молодшого шкільного віку з особливими освітніми потребами, необхідно усвідомлювати важливість самого процесу соціальної адаптації. Це підтримка 3 боку дорослого, який вважається важливим гарантом гармонійного входження дітей з особливими освітніми потребами у шкільне життя. Звісно, соціальна адаптація висуває високі вимоги до власних сил такої дитини. Однак якщо всі, хто займається освітнім і виховним процесом дітей молодшого шкільного віку з особливими потребами, готові спрямовувати свою роботу, крім навчання, також на профрілактичні методи їх розвитку, сповідувати особистісно орієнтовану модель освіти для таких дітей, то можна сподіватися, що особливих проблем зі звиканням до школи в цих дітей не буде, вони пройдуть соціальну адаптацію без будь-яких негараздів. 3 огляду на зазначене перед нами постає необхідність допомогти дітям молодшого шкільного віку з особливими освітніми потребами в інтеграції в суспільство, тобто їхній соціальній адаптації.

Варто підкреслити, що діти молодшого шкільного віку з особливими освітніми потребами повинні бути включені в освітній процес, адже освіта $€$ однією з важливих сорер життя людини. Важливим $€$ той фракт, що освітнім і виховним процесом таких дітей займається інклюзивна освіта, яка передбачає їх залучення до однолітків із типовим рівнем розвитку, проте з урахуванням їхніх особливих потреб. На думку 3. Шевців, термін «особливі потреби» використовується щодо осіб, чия соціальна, фрізична або емоційна особливість потребує спеціальної уваги й послуг та яким надається можливість розвинути свій потенціал, зокрема й освітній [10, с. 14]. Н. Сабат розглядає поняття «діти з особливими освітніми потребами» як таке, що охоплює всіх дітей, чиї освітні потреби виходять за межі загальноприйнятої норми. Відповідно, зазначене поняття стосується дітей із порушеннями психофрізичного розвитку, зокрема дітей з інвалідністю, дітей із соціально вразливих груп та інших [8, с. 43]. 3 огляду на це можна стверджувати, що для дітей молодшого шкільного віку з особливими освітніми потребами має бути створене інклюзивне освітнє середовище з розробленими адаптованими освітніми програмами, спеціальним технічним забезпеченням та обов'язково архітектурним перетворенням. Варто підкреслити, що насправді ефективна освіта вимагає не лише створення умов, а й збагачення можливостей освітнього середовища для забезпечення соціальної адаптації дітей молодшого шкільного віку 3 нетиповим рівнем розвитку.

Значущою для нашого дослідження є наукова праця І. Малішевської «ннклюзивне освітнє середовище», у якій авторка охарактеризувала його як певну технологію інклюзивного навчання, спрямовану на досягнення кінцевого результату - успішну соціалізацію дітей і молоді з особливими освітніми потребами. На переконання вченої, таке середовище ґрунтується на принципах інклюзії, враховує об'єктивні й суб'єктивні чинники ефективного розвитку особистості в межах відкритої соціальнопедагогічної системи, спрямоване на досягнення чіткої мети, реалізованої у змісті інклюзивного навчання дітей та молоді з особливими освітніми потребами [6, с. 22].

Останнім часом в Україні збільшується кількість освітніх закладів для дітей молодшого шкільного віку 3 особливими освітніми потребами. Батьки таких дітей мають право вибирати заклад, де буде навчатися їхня дитина, проте з огляду на те, який тип відхилення в розвитку їй притаманний. Кожний заклад для дітей з особливими освітніми потребами має право вирішувати, які засоби він буде використовувати у своєму освітньому процесі для успішної соціальної адаптації дітей. Навчання 
відбувається за адаптованими освітніми програмами для відповідної групи дітей з особливими освітніми потребами (крім розумово відсталих дітей). Проте деякі групи учнів молодшого шкільного віку потребують навчання за індивідуальним планом, використання специфрічних педагогічних методів і технологій, що будуть спрямовані на соціально-педагогічну профрілактику дезадаптації дітей з особливими освітніми потребами.

Процес інклюзивної освіти для дітей з особливими освітніми потребами в єдиному загальноосвітньому просторі - це незворотний процес на сучасному етапі розвитку суспільства та його гуманістичних цінностей. Водночас цей процес може вважатися повноцінним, якщо забезпечує три неодмінні умови: а) навчання кожної дитини відповідно до їі особливих освітніх потреб і розвитку; б) можливість дитини відвідувати освітній заклад, проживаючи в сім'ї, а батькам - виховувати власну дитину; в) розширення кола спілкування дитини та підвищення її соціальної адаптації. Реалізація цих умов потребує зламу стереотипів та опанування нових форм роботи всіх учасників освітнього й виховного процесу [2, с. 248].

Якщо розглянути окреслену проблему більш детально, то можна констатувати, що сьогодні в Україні значно збільшилася кількість освітніх закладів, які перейшли на інклюзивну освіту. Однак, незважаючи на це, залишилося ще багато перешкод для реалізації проєкту, спрямованого на впровадження інклюзивної освіти в загальноосвітні заклади. На нашу думку, найголовнішою перешкодою $€$ архітектурна недоступність освітніх закладів. Далі можна назвати те, що більшість директорів і вчителів загальноосвітніх шкіл не досить обізнані стосовно входження дітей з особливими освітніми потребами у процес навчання у звичайному класі разом із дітьми 3 типовим рівнем розвитку. Своєю чергою батьки дітей з особливими освітніми потребами не вміють та не знають, як відстоювати права своїх дітей на освіту, а головне - відчувають страх перед системою освіти та зазвичай не мають соціальної підтримки. До перешкод також варто віднести психологічний бар'єр, який фрормують страх перед невідомим, психологічна неготовність, небажання змін тощо.

На психологічному рівні сім'я проходить декілька стадій щодо сприйняття дитини з особливими освітніми потребами, зокрема:

1) розгубленість, страх батьків таких дітей. Батьки зазвичай відчувають безпорадність, тривогу за долю дитини. У цей час фрормуються передумови для встановлення соціально-емоційного зв'язку між батьками та дитиною з особливими освітніми потребами;

2) стан шоку батьків, які виховують дитину 3 особливими потребами, що трансформується в заперечення поставленого діагнозу;
3) депресія в міру прийняття фракту наявності в дитини особливих освітніх потреб і правильної оцінки ситуації;

4) психічна адаптація на основі повного прийняття батьками особливих потреб у дитини;

5) характерна вмотивована поведінка батьків дитини 3 особливими освітніми потребами, коли вони активно шукають допомогу для дитини, будують плани на її майбутнє [4, с. 96-97].

Як показують дослідження та практика, незначна частина сімей досягає останніх двох стадій.

Головними агентами шкільної соціалізації $€$ насамперед учителі, вихователі групи подовженого дня, спеціальні педагоги, соціальні педагоги, практичні психологи та соціальні працівники, які під час виконання покладених на цей інститут завдань повинні створити проміжну модель відносин дітей із соціальним світом. Хоча соціалізуюча функція зазначених агентів на цьому етапі помітно наближається до виховної, між ними $є$ певна розбіжність. Якщо реалізація виховної фрункції має на меті забезпечити опанування дитиною духовно-моральних, естетичних та інших цінностей, то соціалізуюча фрункція передбачає підготовку дитини з особливими потребами до відносин із реальним соціальним середовищем, яке, на відміну від педагогічно орієнтованого, характеризується стихійністю, неоднозначністю, існуванням суперечливих ідей і цінностей [4, с. 99].

Важливою є думка О. Рассказової, яка наголошує на необхідності введення у штат школи 3 інклюзивною освітою додаткових посад соціального педагога для кожної освітньої ланки та створення соціально-педагогічної служби, що поєднуватиме діяльність соціальних педагогів, соціальних працівників, реабілітологів, педагогів спеціальної освіти. Науковиця зазначає: «Особистісний компонент є стрижневим у формуванні професійної культури соціального педагога інклюзивної школи, оскільки він зумовлює толерантне й гуманне ставлення до проблем дітей з особливими освітніми потребами та їхніх родин, культуру поведінки, педагогічний такт, сприяє фрормуванню суб'єктної позиції педагога, що постає дієвим прикладом для учнів» [7, с. 76-77].

В. Костіна визначає важливість розвитку в соціального педагога, який працює в інклюзивному освітньому середовищі, соціального компонента професійної культури, до якого дослідниця відносить такі характеристики: соціальну перцепцію професії, усвідомлення ії соціальної значущості й престижу, наявність особистої та соціальної відповідальності, загострене почуття добра і справедливості, виявлення милосердя, почуття власної гідності та поваги до інших, толерантність, ввічливість, порядність, готовність прийти на допомогу, емоційну стійкість, візуальність, красномовність, 
адекватність самооцінки, соціальну адаптованість тощо [5, с. 141].

Реальністю $є$ те, що діти з особливими освітніми потребами, які закінчують школи-інтернати або навчаються вдома, мають дуже серйозні проблеми із соціалізацією. Нерідко вони не впевнені в собі, несамостійні, у них відсутні соціальні компетенції, їм складно реалізувати себе, отримати вищу чи спеціальну освіту, працевлаштуватися тощо. Натомість інклюзія передбачає, що дитина з раннього віку перебуває в соціумі, вчиться виживати. У дітей $з$ особливими освітніми потребами $€$ можливості для налагодження дружніх стосунків із ровесниками, у яких типовий рівень розвитку та участі у громадському житті. 3 іншого боку, здорові діти, які з першого класу навчаються 3 дітьми з особливими освітніми потребами, у дорослому віці по-іншому ставляться до людей з обмеженими можливостями (уже не із жалістю чи презирством, а нарівні), навчаються природно сприймати та толерантно ставитися до людських відмінностей, а також налагоджувати й підтримувати дружні стосунки $з$ людьми.

Важливу роль у соціальній адаптації дітей молодшого шкільного віку з особливими освітніми потребами відіграють заклади позашкільної освіти, у яких: 1) задовольняються інтереси, індивідуальні потреби таких дітей у сорері культури, мистецтва, наукових знань, техніки, природи, виробництва, життєвих навичок; 2) створюються сприятливі умови для розвитку творчої особистості, забезпечується соціальний захист, організація змістовного дозвілля відповідно до здібностей та особливостей дітей молодшого шкільного віку з особливими освітніми потребами; 3) розв'язуються проблеми соціальної адаптації дітей до нових умов життя; 4) відбувається становлення їхнього соціального досвіду; 5) спостерігається вільний розвиток особистості, розширення ступенів ії самостійності, а найголовніше - забезпечуються умови для здобуття знань, фрормування вмінь і навичок відповідно до особливостей дітей.

Варто підкреслити, що важливим суспільним інститутом соціалізації дітей молодшого шкільного віку з особливими освітніми потребами є дитячі громадські організації та дитячі об'єднання. Як показують емпіричні дані, участь у діяльності таких організацій сприяє вияву самостійності дітей з особливими потребами, реальній їх участі в житті суспільства, задоволенню їхніх потреб у спілкуванні з однолітками, самоствердженню в суспільно значущій діяльності.

Усупереч наявним проблемам нині в Україні щодо дітей молодшого шкільного віку з особливими освітніми потребами вживаються заходи, націлені на реалізацію їхніх соціальних потреб, створюється система соціальних служб, центрів соціально-психологічної реабілітації, що дає змогу підтримувати, реабілітувати цих дітей, допомагати їм, розробляти нові фрорми та види соціальної допомоги цим дітям і їх підтримки. Одним із найважливіших аспектів роботи фрахівців із дітьми молодшого шкільного віку 3 особливими освітніми потребами є інтеграція таких дітей та повна соціальна адаптація. Однак необхідно зауважити, що в більшості спеціалізованих центрів працюють мультидисциплінарні команди фрахівців, зокрема: логопед, дефектолог, реабілітолог, психолог, соціальний педагог та соціальний працівник.

3 огляду на зазначене можемо стверджувати, що соціальна адаптація дітей молодшого шкільного віку з особливими освітніми потребами - це процес їх пристосування до умов соціального середовища та інтеграції в різні типи соціальних спільнот для повноцінного життя; формування адекватної системи відносин із соціальними об'єктами, засвоєння та прийняття соціальних норм і цінностей нового соціального середовища; фрормування соціального досвіду, становлення й розвиток дитини як цілісної особистості, сприйняття суспільством дітей із такими потребами як партнерів у взаємодії.

Одним із завдань наукового дослідження було виявлення рівня соціальної адаптації дітей молодшого шкільного віку з особливими освітніми потребами. Для його вирішення нами було визначено такі компоненти соціальної адаптованості дітей молодшого шкільного віку з особливими освітніми потребами, як анатомо-срізіологічний, мотиваційний, емоційний та комунікативний, які своєю чергою характеризувалися за показниками для більш широкого й різностороннього дослідження проблеми.

На основі виділених чотирьох компонентів соціальної адаптованості дітей молодшого шкільного віку з особливими освітніми потребами проведено експериментальне дослідження, яке здійснювалося в чотири етапи. На першому етапі виявляли дітей молодшого шкільного віку 3 особливими освітніми потребами на основі висновку інклюзивного ресурсного центру. На другому етапі дослідження було поставлено за мету виявити рівень шкільної мотивації та адаптації за допомогою анкети «Дослідження рівня шкільної мотивації й адаптації» Н. Лусканової. Третій етап експериментального дослідження спрямовувався на визначення рівня тривожності в дітей молодшого шкільного віку за допомогою методики діагностики тривожності в дітей молодшого шкільного віку (Р. Теммл, М. Доркі, В. Амен). На останньому, четвертому, етапі експериментального дослідження визначали рівень соціальної адаптованості дітей молодшого шкільного віку з особливими освітніми потребами за допомогою авторського опитувальника «Визначення рівня соціальної адаптованості 
дітей молодшого шкільного віку 3 особливими освітніми потребами».

На основі вказаних компонентів були виявлені такі рівні соціальної адаптації дітей молодшого шкільного віку з особливими освітніми потребами: низький, середній і достатній.

В експерименті взяли участь діти молодшого шкільного віку з особливими освітніми потребами, які були поділені на дві групи - контрольну та експериментальну.

Виявлено достатній рівень соціальної адаптованості в дітей молодшого шкільного віку з особливими освітніми потребами в експериментальній і контрольній групах однаково - у 12,5\% респондентів. Середній рівень в експериментальній групі мають 50\% дітей, а в контрольній - 75\% осіб. Низький рівень соціальної адаптованості (дезадаптації) мають 37,5\% дітей молодшого шкільного віку 3 особливими освітніми потребами експериментальної групи, а таких дітей у контрольній групі виявлено значно менше - 12,5\% осіб. Отже, більшість дітей молодшого шкільного віку з особливими освітніми потребами мають середній і низький рівні соціальної адаптованості. Це значить, що в таких дітей проблем із соціальною адаптацією багато та їм потрібна допомога в їх вирішенні.

Для розв'язання виявлених проблем розроблено та апробовано дослідно-експериментальну програму щодо профрілактики дезадаптації дітей молодшого шкільного віку з особливими освітніми потребами, яка передбачала врахування чотирьох компонентів соціальної адаптованості дітей молодшого шкільного віку з особливими освітніми потребами (анатомо-фрізіологічного, мотиваційного, емоційного та комунікативного). Мета програми полягала у створенні позитивного емоційно забарвленого клімату серед дітей молодшого шкільного віку з особливими освітніми потребами, а також у фрормуванні соціальної довіри, адекватної самооцінки, розвитку комунікативних навичок для соціальної адаптації дітей із нетиповим рівнем розвитку.

Формувальний етап експерименту мав чотири стадії. На першій стадії була проведена робота 3 метою визначити на основі висновку інклюзивного ресурсного центру напрям роботи 3 дітьми молодшого шкільного віку з особливими освітніми потребами. На другій стадії формувального експерименту було здійснено роботу щодо розвитку мотиваційного компоненту соціальної адаптованості дітей молодшого шкільного віку з особливими освітніми потребами 3 метою оволодіння методами активізації мотивації учіння та скеровування цих умінь під час виконання освітньої діяльності. Третя стадія фрормувального експерименту була спрямована на розвиток емоційного компоненту соціальної адаптованості дітей молодшого шкільного віку з особливими освітніми потребами за допомогою корекційної програми, спрямованої на зниження рівня тривожності, подолання негативних проявів у спілкуванні та гуманізацію міжособистісних стосунків дітей із нетиповим рівнем розвитку.

Розроблений комплекс критеріїв і показників сорормованості компонентів соціальної адаптованості дітей молодшого шкільного віку з особливими освітніми потребами дав можливість оцінити ефективність цієї роботи та зафіксувати зміни за всіма рівнями. Так, у контрольній групі зрушень майже не відбулося: на низькому рівні результат не змінився зовсім, змінився лише на середньому й достатньому рівнях на незначний відсоток (середній рівень початково мали 75\% реципієнтів, а потім їх стало 62,5\%, натомість достатній рівень продемонструвала ще одна особа - він зріс до 25\% респондентів). Однак необхідно враховувати, що такі діти, як уже зазначалося, дуже мінливі у своїй поведінці, залежні від різних факторів, вони можуть демонструвати відразу два рівні, тому ми не впевнені, що ці зміни справді відбулися, адже належна робота 3 дітьми молодшого шкільного віку з особливими освітніми потребами контрольної групи не проводилася.

В експериментальній групі динаміка зрушень відбулася на всіх трьох рівнях, зокрема: низький рівень продемонстрували лише 12,5\% респондентів (початково було 37,5\% осіб), середній рівень у цій групі виявлено в $62,5 \%$ реципієнтів (було у 50\% дітей), а достатній рівень - у 25\% осіб із нетиповим рівнем розвитку (до експерименту його демонстрували лише $12,5 \%$ респондентів). Це дає підстави стверджувати, що ефект змін зумовлений упровадженням в інклюзивне освітнє середовище програми, спрямованої на організацію ефективного процесу соціальної адаптації дітей молодшого шкільного віку 3 особливими освітніми потребами.

Висновки. Аналіз результатів підтвердив, що після проведення фрормувального експерименту, а саме занять для успішної соціальної адаптації дітей молодшого шкільного віку з особливими освітніми потребами, відбулися позитивні зміни в експериментальній групі, що є підставою для подальшого впровадження зазначеної програми в освітній процес інклюзивних закладів.

У межах отриманих результатів можна окреслити перспективу подальшого дослідження в цьому напрямі - соціальну адаптацію студентської молоді з особливими освітніми потребами в закладах вищої освіти.

\section{БІБЛІОГРАФІЧНИЙ СПИСОК:}

1. Андреева Г. Социальная психология. Москва : Аспект-Пресс, 1996. 376 с.

2. Дитинство в Україні: права, гарантії, захист : збірник документів : у 2 ч. Київ : АТ «Видавництво “Столиця"», 1998. Ч. 2. 248 с. 
3. Енциклопедія для фрахівців соціальної сфери / за заг. ред. І. Звєрєвої. 2-ге вид. Київ ; Сімферополь : Універсум, 2013. 536 с.

4. Порошенко М. Інклюзивна освіта : навчальний посібник. Київ : ТОВ «Агентство “Україна"», 2019. 300 с.

5. Костіна В. Професійна підготовка майбутніх фахівців соціальної галузі до профрілактики дезадаптації учнів у різних соціальних інституціях : монографія. Харків : ХОГОКЗ, 2018. 364 с.

6. Малішевська І. Інклюзивне освітнє середовище: ґенеза поняття. Особлива дитина: навчання і виховання. 2016. № 3. С. 19-26.
7. Рассказова О. Соціальний педагог - суб'єкт розвитку соціальності учнів в інклюзивній школі. Соціальна педагогіка: теорія і практика. 2013. № 4. C. 72-79.

8. Сабат Н. Соціально-педагогічний аспект інклюзивного навчання. Соціальний педагог. 2008. № 3. С. $42-46$.

9. Швед М. Основи інклюзивної освіти : підручник. Львов : Український католицький університет, 2015. $360 \mathrm{c}$.

10. Шевців 3. Основи інклюзивної педагогіки : підручник. Київ : Центр учбової літератури, 2016. 248 с. 